\title{
Pre-Service Teachers' Perception of Online Teaching and Learning during the COVID - 19 Era
}

\author{
Anna Mwinbuabu Naah \\ Offinso College of Education, Ashanti-Ghana W/A
}

\begin{abstract}
The disclosure of COVID - 19 saw an increasing popularity of Information technology. Most of the educational institutions has resort to online teaching and learning. The purpose of the study was intended to find out pre-service teachers' perception of online teaching and learning during the COVID - 19 era. In this study, a quantitative descriptive survey research design was adopted.The research instrument that was used to collect the data was questionnaire. The items on the instrument that is the questionnaire were selfdeveloped by the researcher for this study. The non-probability sampling technique namely purposive sampling was employed to select the respondents from Offinso College of Education in the Ashanti Region.A total of 94 pre-service teachers participated in the study. Out of this total, 49 females and 45 males, were pre-service teachers' trainees on a 4-year Bed Primary Education Programme pursuing General Chemistry as one of their core courses.

The results from the study showed that most of the pre-service teachers' had an idea of the units taught for the semester.Pre-service teachers' expressed great need for lessons to be delivered using video and audio as it makes lesson real and also see their tutor even though it required much data to access video.The preservice teachers' expressed great interest in tutors using trial questions and quiz in assessing them and responds from assessment should be submitted through what's up platform. With all the challenges preservice teachers' encountered during online teaching and learning they appreciated the tutor-learner relationship and interactions as cordial, collaborative and done in a form of discussion. It is therefore recommended that there should be stable network connectivity and subside on data bundle for learners.
\end{abstract}

Keywords: COVID-19, WASSCE, UNESCO, Trial questions, Quiz, Activity and Exercise.

\section{Background to the Study}

COVID - 19(corona virus) is an infectious deadly disease that has impacted greatly on global economy. The pandemic has not only impacted human life but also impacted on education. The least was expected on its impact on education. The educational sector was taken by surprise when the tragic shook up the sector in shambles.Theinterference of the educational sector during COVID - 19cannot be under estimated worldwide. The emergence of the COVID - 19 pandemic has witnessed educational disruption on such a large scale, UNESCO (2020). The Covid-19 pandemic outbreak forced all universities, polytechnics, colleges, secondary schools and the basic schools to remain closed temporarily as was the case in Ghana.

The disclosure of COVID - 19 saw an increasing popularity of Information technology. Most of the educational institutions has resort to online teaching and learning. The swift shift from the face to face or the normal classroom interaction to the online interaction between the teacher and learner emerged with a lot of challenges. Both the teacher and the learner had to adjust to the new ways of interacting during teaching and learning, with the teacher canvasing for new methods of teaching and learners adjusting to the new ways of learning. These challenges included learning how to interacting with learners online, how to assess learners online, appropriate technological device to use, access to internet connectivity, funds for data and howthe teacher will provided feedbacks to learners and vice versa.

With all these challenges stakeholders in the education sector including heads of institutions administrators, teachers, parents, andstudents are takingimportantstrides to ideallyengage learners with the available technology for continuanceof teaching and learning and to bridge the gaps that will be created in the 
ensuring years as a result of the saga surrounding the COVID -19 pandemics. This has paved way for the information technologist and software developers to be more innovative. Theflourishing innovative technologies and learning management systems for teaching, learning and assessment hasmade headway by providing a working solution for educators and giving policy makers an opportunity to implement the use of information technology during this period for covering the course work (Abbasi, Ayoob, Malik,\&Memon, 2020).

The teaching and learning process can be more leaner-centered, more innovative, and even more flexible when online is used as tool. According to Singh and Thurman (2019) online teaching and learning is defined as learning experiences in synchronous or asynchronous environments using different devices such as mobile phones, laptops, etc. with internet access. In this process the learner can be anywhere to interact and learn with the teacher and other learners. Furthermore online teaching and learning is defined as is a form of education that uses the Internet to convey some form of instruction to a learner or the learners is separated by timeand or distance (Dempsey \& Van Eck, 2002). There are diverse forms of online teaching and learning, such as synchronous and asynchronous online teaching and learning. Synchronous online teaching and learning is time dependent and space independent where as asynchronous online learning means time independent and space independent online learning (Cereijo, Young, \& Wilhelm, 2001). Some online teaching and learning takes both synchronous and asynchronous forms.

One can have access to a quality education whenever and wherever you want to, as long as you have access to a computer. Online education is flexible, itenables the teacher and the leaner to set their own learning pace, and there's the added flexibility of setting a schedule that fits everyone's agenda and allows for a better balance of work and studies. Online education offers a wide selection of programs. It is easily accessible, one study or teach from anywhere in the world without the need to travel follow a rigid schedule. It allows for a customized learning experience (Josep, 2020). There's often access to very diverse material such as videos, photos, and eBooks online as well, and tutors can also integrate other formats like forums or discussions to improve their lessons.

Dhawan (2020) attest to the fact that online teaching and learning enable educators to customize their procedures and processes based on the needs of the learners. He further explained that there are plenty of online tools available which is important for an effective and efficient teaching and learning processes. Thus educators can use a combination of audio, videos, and text to reach out to their learners in this time of crises to sustain a human touch to their lessons. This can bring about creating a collaborative and interactive learning process where learners can give their immediate feedback, ask questions, and learn interestingly.From a research study, effective online learning deal with careful instructional design and planning, with a systematic model for design and development, Branch and Dousay (2015). The process of the design and the careful consideration of different design decisions have an impact on the quality of the instruction. However, it is this careful design process that will be missed in most situations in these emergency shifts (Hodges, Moore, Lockee, Torrey Trust, \& Bond, 2020).

Online education tends to be more affordable, it is more cost-effective than traditional education (Josep, 2020). Nonetheless, a number of arguments are associated with online teaching and learning. Accessibility, affordability, flexibility, learning pedagogy, life-long learning, and policy are some of the issues related to online instructions (Dhawan, 2020). Teaching and learning using the online approach has a lot of challenges ranging from learners' issues, educators' issues, and content issues (Kebritchi, Lipschuetz, \& Santiague, 2017). They further explained it was a challenge for institutions to engage learners and make them participate in the teaching-learning process. It was also a challenge for teachers to move from face to face in class mode to online mode, changing their teaching methodologies, and managing their time. And it was a challenge to develop content which did not only covers the curriculum but also engage the learners. A study carried out on orthopedic surgery residents' perception of online education in their programs during the COVID-19 pandemic: should it be maintained after the crisis?, Figueroa, Figueroa, Calvo-Mena, Narvaez, Medina and Prieto (2020) reported technical problems were still important during online activities that required more data transmission than the regular amount, with loss of connection or delay and decrease of fluency. 
Li and Lalani (2020) recount some students without reliable internet access and/or technology struggle to participate in digital learning; this gap is seen across countries and between income brackets within countries. For some who have access with the right technology, there is evidence that learning online can be more effective but it effectiveness varies amongst age groups. The overall consensus on children, especially younger ones, is that a structured environment is required, because kids are more easily distracted. Loeb (2020) is of the view that online teaching and learning are generally not as effective as in-person classes, but they are certainly better than no classes. Thus virtual learning are allowing leaners to access lessons and exercises and interact with teachers in ways that would have been impossible if an epidemic had closed schools even a decade or two earlier.

In addition, Demuyakor, J. (2020)conducted a study oncoronavirus (COVID -19) and online learning in higher institutions of educationand reported that expected challenges studentsencounter during the online teaching and learning identified high cost of internet data for students who are currently outside China. The difference in time zone was also recognized as a severe challenge to online learning. At the same time, students who were still within China and were staying on the various university dormitories complain of the slow nature of the internet. Also student's recorded high mean score of 3.77 as online learning as very useful, effective and credible of the course content learnt, and a few with mean score of 0.23 shows that students are positively contributing to the ineffectiveness of online learning.Research study by Kaden (2020) on COVID - 19 school closure-related changes to the professional life of a $\mathrm{K}-12$ teacher, the results demonstrated an increase and change in workload for the teacher and thatonline education can support learning for many students but needs to be carefully designed and individualized to not deepen inequality and social divides. The compulsory move to online learning may have been the catalyst to create a new, more effective hybrid model of educating students in the future. Also online lessons showed is diversified and individualized assessmentsusing video reporting, digital storytelling, orscienceexplorationsinthebackyardengagedstudentsandthattheyhadfun.

\section{Statement of the Problem}

Technology has and will continue to reshape the world. Online system of education is viewed as relatively new, according to research, in the future, it will just be as effective as school-based methods (UNESCO, 2020). Many institutions in Ghana require academic faculty to design and develop their own digital course content. Lack of adequate training, compensation and support systems, and dedicated offices and instruments to guide the processes of content design and development, compelled many lecturers to post course online and notes that were originally structured for physical face to face classroom interactions (Larbi-Apau Sampong \& Kwofie (2020). This resulted in lack of knowledge in internet etiquette of code of conduct of the teacher and the leaner, keeping messages or chart short, avoid sarcasm or the use of phrases or words that could offend the reader or the listener, etc.

Larbi-Apau, Sampong and Kwofie (2020) in their study of barriers to online learning adoption in higher education were confident to say that the existing physical structures in higher education systems in Ghana are not designed to support emerging educational technologies. Many of the systems are constrained by Information Communication and Technology (ICT) infrastructure such as poor network security, inadequate wireless technologies and low-speed internet bandwidths. It also included ineffective infrastructure management to ensure contributions of technology as a means to improving learner learning.In contrast to developed countries where a team of experts are usually engaged to design and develop online courses and instructions, many institutions in Ghana require academic faculty to design and develop their own digital course content.

Considering pre-service teachers as adult learners at the tertiary level in education, it will be expected these leaners can manage their time effectively and develop communication and technological skills. Pre-service teachers must be dynamic, exhibit commitment and accept the flexibility that goes with online teaching and learning. Nevertheless, these internal conditions and expectations of Pre-service teachers may be challenged by poor internet access, lesson delivery and assessment challenges, and lack of interest in online lessons. These initiated the researcher to explore pre-service teachers' perception of online teaching and learning during the COVID - 19 eras.

\section{Research Questions}


1. What is pre-service teachers' content knowledge of units covered in the semester?

2. How much satisfied are the pre-service teachers' with online lessons delivery?

3. What are pre-service teachers' views on online assessment?

4. What is the tutor - pre-service teacher relationship and interaction during online teaching and learning?

5. What are pre-service teachers' general impression with regards to online teaching and learning?

\section{Methods}

The purpose of the study was intended to find out pre-service teachers perception of online teaching and learning during the COVID 19 era. In this study a quantitative descriptive survey research design was adopted. This choice was premised on the nature of the study's objectives. The descriptive survey design method is an efficient approach in gathering data about perceptions from a population sample. The research instrument that was used to collect the data was questionnaire. The items on the instrument that is the questionnaire were self-developed by the researcher for this study. Experts at the Department of Science and Physical Education at the Offinso College of Education affiliated to the University of Cape Coast, read through the items on the questionnaire to examine the face and content validity in order to ensure that they were devoid of ambiguities vis-à-vis the research questions.

A pilot-study was carried out on the feasibility ratings of the reliability of the data collection instrument. This was to ascertain whether the instrument was measuring what it was supposed to measure. One of the Colleges of Education and affiliate of the University of Cape Coast in the Bone East Region was sampled during the pilot-study. Pre-service teachers' of this College are 4 Year Bed Primary Education students who offer the General Chemistry as a core course. It was assumed these students have similar characteristics as those at the College in the Ashanti Region where the actual study took place. All the pre-service teachers selected for the pilot study had the minimum qualification in education at the Senior High School and holds a certificate in West Africa Senior School Certificate Examination (WASSCE).

Primary data was collected using a closed-ended questionnaire. The data was analyzed using SPSS version 20. The study employed Cronbach's alpha to test the internal consistency and reliability of the questionnaire for each domain. The Cronbach's alpha values were as follows: (1) content knowledge (0.87); (2) lesson delivery $(0.78)$; (3) mode of assessment $(0.71)$; (4) tutor - pre-services interaction (0.91); and (5) pre-service teachers' impression (0.79). From the analysis of the data collected from the pilot-study, some of the items with negative reliability were deleted whiles others with negative wordings were reframed to get the reliabilities.

A total of 94 pre-service teachers participated in the actual study. Out of this total, 49 females and 45 males, were pre-service teachers' trainees on a 4 year Bed Primary Education Programme offering General Chemistry as one of their core courses. The non-probability sampling technique namely purposive sampling was employed to select the respondents from Offinso College of Education in the Region. The purposive sampling technique was employed to select all first year pre-service teachers on the Primary Education programme offering General Chemistry as one of their core course. These groups of people were purposefully sampled because they were considered the right people to provide useful information.

Before administering questionnaire to the respondents online, a request was made to both the group administrators and members of the Department of Science and Physical Education at the Offinso College of Education of the intent of the survey, and questionnaire was posted on the pre-service teachers' what's up group platform. Responses from the respondents were received through the researchers e-mail and personal what's up platform. Data collected from respondents were coded, scored and scores entered into the computer. Descriptive and frequency statistics were carried out on the data using the Statistical Package for Social Sciences (SPSS) software version 20.

\section{Results}

The study was intended to find out pre-service teachers perception of online teaching and learning during the COVID - 19 era. Descriptive and frequencies statistics were carried out on the data using SPSS software version 20. Tables are provided to illustrate and support the findings. The results is organized and presented under the following sections: 
Demographics

Pre-service teachers' knowledge of course content

Mode of online lessons delivery by course tutor

Mode of online lessons assessment by course tutor

Tutor learner relationship and interaction on online teaching and learning

General impression with online teaching and learning

\section{Demographics}

A total of 94 pre-service teachers participated in the study. Out of this total, 49 females and 45 males, were pre-service teacher trainees on a 4 year Bed Primary Education Programme offering General Chemistry as one of their core courses. The ages of the pre-service teachers ranged from 19 to 28 years with an average age of approximately 22 years. The pre-service teachers had some pre requisite knowledge in integrated science at the Senior High School and at least had a credit pass in the subject before gaining admission into the College of Education.

\section{Pre-service teachers' knowledge of course content}

The pre-service teachers' knowledge of the course content of General Chemistry thought for the semester was investigated. The respondents were asked to indicate the course name, curse title, the number of credit hours the course merit and units covered. Out of the 94 respondents more than half of the respondent expressed knowledge of the course name, and the number of credit hours for the course (table 1a) with a mean value of $1.21 \pm 0.41$ and $1.35 \pm 0.48$ respectively. Most of the respondent had knowledge of the units of the course treated for the semester with a mean value of $4.38 \pm 1.96$. The respondent also displayed varied views on units enjoyed most during the online teaching and learning, and units best thought using the online teaching approach (table 1a).

Table 1: Distribution of Pre-Service Teachers' Knowledge of Course Content (n=94)

\begin{tabular}{|l|l|l|}
\hline Items & Mean & Standard Deviation \\
\hline Course name & 1.21 & 0.41 \\
\hline Course title & 1.50 & 0.68 \\
\hline Number of credit hours & 1.35 & 0.48 \\
\hline Units covered for the semester & 4.38 & 1.96 \\
\hline $\begin{array}{l}\text { Which of the units did you enjoyed most } \\
\text { during the online teaching }\end{array}$ & 2.93 & 1.69 \\
\hline $\begin{array}{l}\text { Which of the topics was best thought } \\
\text { using the online teaching approach }\end{array}$ & 3.05 & 1.80 \\
\hline
\end{tabular}

Source: Field of Study, 2020

Table 1(a): Frequency Distribution of Pre-Service Teachers' Knowledge of Course Content (n=94)

\begin{tabular}{|l|l|l|}
\hline Items & Frequency & Percentage \\
\hline Course name & \multicolumn{2}{l|}{} \\
\hline Response & 74 & 78.7 \\
\hline Yes & 20 & 21.3 \\
\hline No & 94 & 100.0 \\
\hline Total & \multicolumn{2}{l|}{} \\
\hline Course title & \\
\hline Response &
\end{tabular}




\begin{tabular}{|c|c|c|}
\hline Yes & 52 & 55.3 \\
\hline No & 42 & 44.7 \\
\hline Total & 94 & 100.0 \\
\hline \multicolumn{3}{|l|}{ Number of credit hours } \\
\hline \multicolumn{3}{|l|}{ Response } \\
\hline Yes & 61 & 64.9 \\
\hline No & 33 & 35.1 \\
\hline Total & 94 & 100.0 \\
\hline \multicolumn{3}{|l|}{ Units covered for the semester } \\
\hline \multicolumn{3}{|l|}{ Response } \\
\hline One unit & 16 & 17.0 \\
\hline Two units & 3 & 3.2 \\
\hline Three units & 14 & 14.9 \\
\hline Four units & 5 & 5.3 \\
\hline Five units & 8 & 8.5 \\
\hline Six units & 48 & 51.1 \\
\hline Total & 94 & 100.0 \\
\hline \multicolumn{3}{|c|}{ Which of the units did you enjoyed most during the online teaching } \\
\hline \multicolumn{3}{|c|}{ Response } \\
\hline Structure of an atom & 27 & 28.7 \\
\hline Electronic configuration & 20 & 21.3 \\
\hline Chemical bonding & 12 & 12.8 \\
\hline Covalent bonding & 7 & 7.4 \\
\hline The mole and formula mass & 24 & 25.5 \\
\hline Chemical formula and equations & 4 & 4.3 \\
\hline Total & 94 & 100.0 \\
\hline \multicolumn{3}{|c|}{ Which of the units was best thought using the online teaching approach } \\
\hline \multicolumn{3}{|c|}{ Response } \\
\hline Structure of an atom & 27 & 28.7 \\
\hline Electronic configuration & 19 & 20.2 \\
\hline Chemical bonding & 10 & 10.6 \\
\hline Covalent bonding & 7 & 7.4 \\
\hline The mole and formula mass & 22 & 23.4 \\
\hline Chemical formula and equations & 9 & 9.6 \\
\hline Total & 94 & 100.0 \\
\hline
\end{tabular}

Source: Field study, 2020 


\section{Mode of online lessons delivery by course tutor}

To ascertain the current state of the mode of delivery, the respondents were asked to indicate their views on the online lessons delivery by course tutor. From Table 2 a the responses of the pre-service teachers indicated that currently audio and video should be used during lessons delivery and the platform for the lesson delivery they require is the What's up and supported by zoom. The respondents had what it take to access online teaching and learning. Almost all of them have either smart or an android phone with mean value of $3.48 \pm 0.77 \mathrm{~s}$. d. However, online lesson delivery is seen as boring and intimidating and the pace of delivery is slow (table 2).

Table 2: Distribution of the Mode of Online Lessons Delivery by Course Tutor $(n=94)$

\begin{tabular}{|l|l|l|}
\hline Items & Mean & $\begin{array}{l}\text { Standard } \\
\text { Deviation }\end{array}$ \\
\hline How best should the tutor had thought these units & 2.46 & 1.96 \\
\hline $\begin{array}{l}\text { Which online platform will you suggest is appropriate for teaching general } \\
\text { chemistry }\end{array}$ & 3.17 & 1.44 \\
\hline $\begin{array}{l}\text { Which online platform will you suggest is appropriate for tutors to use in } \\
\text { teaching general chemistry }\end{array}$ & 3.22 & 1.35 \\
\hline Which online platform is available and easily accessible for your learning & 2.43 & 0.89 \\
\hline $\begin{array}{l}\text { What technological device (s) do you use for your online teaching and } \\
\text { learning process }\end{array}$ & 3.48 & 0.77 \\
\hline Pace of delivery during online teaching and learning is & 1.72 & 0.72 \\
\hline The mode of delivery during online teaching and learning is & 1.83 & 0.81 \\
\hline
\end{tabular}

Source: Field of Study, 2020

Table 2b: Frequency Distribution of Mode of Online Lessons Delivery by Course Tutor $(n=94)$

\begin{tabular}{|l|l|l|}
\hline Items & Frequency & Percentage \\
\hline How best should the tutor had thought these units & \multicolumn{2}{|l|}{} \\
\hline Response & 46 & 48.9 \\
\hline Use videos and audios during lessons & 17 & 18.1 \\
\hline Have enough time to explain and interact with pre-service teachers' & 5 & 5.3 \\
\hline Give a lot of examples or illustrations & 13 & 13.8 \\
\hline Engage pre-service teachers' in a lot of activities & 3 & 3.2 \\
\hline Involve pre-service teachers' in lesson delivery & 4 & 4.3 \\
\hline Give a lot of assignments & 3 & 3.2 \\
\hline Give notes in advance before the lesson & 3 & 3.2 \\
\hline Teach continuous & 94 & 100.0 \\
\hline Total & 34 \\
\hline Which online platform will you suggest is appropriate for teaching general chemistry \\
\hline Response & \multicolumn{2}{|l}{} \\
\hline Learning management system (LMS) & 4 & 4.3 \\
\hline
\end{tabular}




\begin{tabular}{|c|c|c|}
\hline What's up & 47 & 50.0 \\
\hline Google Classroom & 3 & 3.2 \\
\hline Telegram & 9 & 9.6 \\
\hline Zoom & 31 & 33.0 \\
\hline Total & 94 & 100.0 \\
\hline \multicolumn{3}{|c|}{$\begin{array}{l}\text { Which online platform will you suggest is appropriate for tutors to use in teaching genera } \\
\text { chemistry }\end{array}$} \\
\hline \multicolumn{3}{|l|}{ Response } \\
\hline Learning management system (LMS) & 1 & 1.1 \\
\hline What's up & 47 & 50.0 \\
\hline Google Classroom & 3 & 3.2 \\
\hline Telegram & 16 & 17.0 \\
\hline Zoom & 27 & 28.7 \\
\hline Total & 94 & 100.0 \\
\hline \multicolumn{3}{|c|}{ Which online platform is available and easily accessible for your learning } \\
\hline \multicolumn{3}{|l|}{ Response } \\
\hline Learning management system (LMS) & 0 & 0.00 \\
\hline What's up & 74 & 78.7 \\
\hline Google Classroom & 5 & 5.3 \\
\hline Telegram & 10 & 10.6 \\
\hline Zoom & 5 & 5.3 \\
\hline Total & 94 & 100.0 \\
\hline \multicolumn{3}{|c|}{ What technological device (s) do you use for your online teaching and learning process } \\
\hline \multicolumn{3}{|l|}{ Response } \\
\hline Desk top computer & 3 & 3.2 \\
\hline Lap top computer & 4 & 4.3 \\
\hline Smart phone & 35 & 37.2 \\
\hline Android phone & 49 & 52.1 \\
\hline Tablet & 3 & 3.2 \\
\hline Total & 94 & 100.0 \\
\hline \multicolumn{3}{|c|}{ Pace of delivery during online teaching and learning is } \\
\hline \multicolumn{3}{|l|}{ Response } \\
\hline Fast & 36 & 38.3 \\
\hline Slow & 58 & 61.7 \\
\hline Total & 94 & 100.0 \\
\hline
\end{tabular}




\begin{tabular}{|l|l|l|}
\hline Response & 40 & 42.6 \\
\hline Boring & 30 & 31.9 \\
\hline Intimidating & 24 & 25.5 \\
\hline Interesting & 94 & 100.0 \\
\hline Total & 94 \\
\hline
\end{tabular}

Source: Field of Study, 2020

Mode of online lessons assessment by course tutor

With regards to knowledge on the mode of online lessons assessment by course tutor, the pre-service teachers'response indicated they were interested in trial questions and quiz (table 3a), and that these should be used in assessing them. They were of the view that the trial questions and quizzes be submitted through what's up even though there are challenges with network connectivity (table 3a).

Table 3: Distribution of Mode of Online Lessons Assessment by Course Tutor (n=94)

\begin{tabular}{|l|l|l|}
\hline Items & Mean & Standard Deviation \\
\hline $\begin{array}{l}\text { Which do you enjoy most with } \\
\text { online assessment }\end{array}$ & 2.03 & 1.05 \\
\hline $\begin{array}{l}\text { Which of these mode of assessment } \\
\text { should tutors use in assessing pre- } \\
\text { service teachers }\end{array}$ & 2.07 & 1.07 \\
\hline $\begin{array}{l}\text { State the platform through which } \\
\text { assessment response should be send } \\
\text { to tutors }\end{array}$ & 2.04 & 0.77 \\
\hline $\begin{array}{l}\text { What are some of the challenged you } \\
\text { face when answering question } \\
\text { online? }\end{array}$ & 2.05 & 1.35 \\
\hline $\begin{array}{l}\text { What are some of the challenged you } \\
\text { face when summiting response from } \\
\text { assigned task }\end{array}$ & 1.79 & 0.95 \\
\hline
\end{tabular}

Source: Field of study, 2020

Table 3(a): Frequency Distribution of Mode of Online Lessons Assessment by Course Tutor

\begin{tabular}{|c|c|c|}
\hline Items & Frequency & Percentage \\
\hline \multicolumn{3}{|c|}{ Which do you enjoy most with online assessment } \\
\hline \multicolumn{3}{|l|}{ Response } \\
\hline Trial questions & 38 & 40.4 \\
\hline Quiz & 27 & 28.7 \\
\hline Activity & 17 & 18.1 \\
\hline Exercise & 12 & 12.8 \\
\hline Total & 94 & 100.0 \\
\hline
\end{tabular}




\begin{tabular}{|c|c|c|}
\hline \multicolumn{3}{|l|}{ Response } \\
\hline Trial questions & 34 & 36.2 \\
\hline Quiz & 35 & 37.2 \\
\hline Activity & 9 & 9.6 \\
\hline Exercise & 16 & 17.0 \\
\hline Total & 94 & 100.0 \\
\hline \multicolumn{3}{|c|}{ State the platform through which assessment response should be send to tutors } \\
\hline \multicolumn{3}{|l|}{ Response } \\
\hline Learning management system (LMS) & 14 & 14.9 \\
\hline What's up & 72 & 76.6 \\
\hline Telegram & 6 & 6.4 \\
\hline Zoom & 2 & 2.1 \\
\hline Total & 94 & 100.0 \\
\hline \multicolumn{3}{|c|}{ What are some of the challenged you face when answering question online? } \\
\hline \multicolumn{3}{|c|}{ Response } \\
\hline Poor network connectivity & 55 & 58.5 \\
\hline Lack of funds to buy data or bundle & 2 & 2.1 \\
\hline $\begin{array}{l}\text { Poor network connectivity and lack of funds } \\
\text { to buy data or bundle }\end{array}$ & 19 & 20.2 \\
\hline Errors or mistakes when typing & 13 & 13.8 \\
\hline $\begin{array}{l}\text { Tutor not responding to all answers posted by } \\
\text { pre-service teachers' on the platform }\end{array}$ & 5 & 5.3 \\
\hline Total & 94 & 100.0 \\
\hline \multicolumn{3}{|c|}{ What are some of the challenged you face when summiting response from assigned task } \\
\hline \multicolumn{3}{|c|}{ Response } \\
\hline Poor network connectivity & 54 & 57.4 \\
\hline Lack of funds to buy data or bundle & 6 & 6.4 \\
\hline $\begin{array}{l}\text { Poor network connectivity and lack of funds } \\
\text { to buy data or bundle }\end{array}$ & 34 & 36.2 \\
\hline Total & 94 & 100.0 \\
\hline
\end{tabular}

Source: Field of Study, 2020

Tutor Learner Relationship and Interaction on Online Teaching and Learning

The pre-service teacher' response to tutor learner relationship and interaction during online teaching and learning were as follows; tutor learner relationship during online teaching and learning was cordial (table 4) whereas tutor learner interaction during online teaching and learning was boring and intimidating (table 4a).

Table 4: Distribution of Tutor Learner Relationship and Interactionon Online Teaching and Learning

\begin{tabular}{|l|l|l|}
\hline Items & Mean & Standard Deviation \\
\hline
\end{tabular}




\begin{tabular}{|l|l|l|}
\hline $\begin{array}{l}\text { Tutor learner relationship during online teaching } \\
\text { and learning is }\end{array}$ & 1.18 & 0.55 \\
\hline $\begin{array}{l}\text { Tutor learner interaction during online teaching } \\
\text { and learning is }\end{array}$ & 2.17 & 1.36 \\
\hline
\end{tabular}

Source: Field of Study, 2020

Table 4(b): Frequency Distribution of Tutor Pre-service TeacherRelationship and Interaction on Online Teaching and Learning

\begin{tabular}{|c|c|c|}
\hline Items & Frequency & Percentage \\
\hline \multicolumn{3}{|c|}{ Tutor pre-service teacher relationship during online teaching and learning is } \\
\hline \multicolumn{3}{|c|}{ Response } \\
\hline Cordial & 84 & 89.4 \\
\hline Intimidating & 10 & 10.6 \\
\hline Total & 94 & 100.0 \\
\hline \multicolumn{3}{|c|}{ Tutor pre-service teacher interaction during online teaching and learning is } \\
\hline \multicolumn{3}{|c|}{ Response } \\
\hline Collaborative & 49 & 52.1 \\
\hline Lecture & 11 & 11.7 \\
\hline Activity oriented & 3 & 3.2 \\
\hline Discussion & 31 & 33.0 \\
\hline Total & 94 & 100.0 \\
\hline
\end{tabular}

Source: Field of Study, 2020

General impression with online teaching and learning

The pre-service teachers' views on general impression with online teaching and learning were solicited. Most of the respondents were of the views that it is good/interesting but data should be provided; good initiative during this COVID 19 era but costly and it should be abolished (table 5a)

Almost all the respondent agreed to the fact that the previous semester teaching and learning (face to face classroom interaction) was better than this semester (online teaching and learning) (table 5)

Table 5: Distribution of Pre-Service Teachers' General Impression with Online Teaching and Learning

\begin{tabular}{|l|l|l|}
\hline Items & Mean & Standard Deviation \\
\hline $\begin{array}{l}\text { What is your general impression for online } \\
\text { teaching and learning }\end{array}$ & 3.28 & 1.30 \\
\hline $\begin{array}{l}\text { Comparing last semesters teaching and learning } \\
\text { processes and this semester online teaching and } \\
\text { learning which one will go for }\end{array}$ & 1.02 & 0.15 \\
\hline
\end{tabular}

Source: Field of Study, 2020 
Table 5(a): Frequency Distribution of Pre-Service Teachers' General Impression with Online Teaching and Learning

\begin{tabular}{|l|l|l|}
\hline Items & Frequency & Percentage \\
\hline What is your general impression for online teaching and learning \\
\hline Response & 10 & 10.6 \\
\hline Not an effective process for teaching and leaning & 19 & 20.2 \\
\hline Boring, should not be encouraged & 20 & 21.3 \\
\hline Good/interesting but provide data & 25 & 26.6 \\
\hline Good initiative but costly & 20 & 21.3 \\
\hline Online teaching should be abolished & 94 & 100.0 \\
\hline Total & 94 & \\
\hline Comparing last semesters teaching and learning processes and this semester online teaching and \\
learning which one will go for
\end{tabular}

Source: Field of Study, 2020

\section{Discussion and Conclusion}

Teaching, learning and assessment are effective when an appropriate pedagogical content knowledge is employed effectively and efficiently before, during and after lesson delivery. It is the dream of every teacher to teach for his or learners to be able to apply the concept been thought to real life situations and to help solve human problems. The swift change in the mode of teaching and learning from the classroom face to face interaction to the online teaching and learning has to be embraced in this trying moments. This initiated the study find out how pre-service teachers' perception with online teaching and learning. The results from the study showed that most of the pre-service teachers' had an idea of the units thought for the semester. This is good indication from the leaners point of view, with all the challenges pre-service teachers' go through they still recall they had instructions on units covered in the semester. However, pre-service teacher had different views on units they enjoyed most and whichwas effectively delivered through online teaching and learning.

Pre-service teachers' expressed great need for lessons to be delivered using video and audio as it makes lesson real and also see their tutor even though it required much data to access video as in accordance with that of Kaden (2020) findings and requires more data transmissionas expressed in line with the finding of Figueroa, Figueroa, Calvo-Mena, Narvaez, Medina and Prieto (2020).Thepre-service teachers' had the right technological tool to facilitate teaching and learning, most had either a smart or an android phone. However, the pace of the lesson delivery to the learners was too slow and was expressed as boring and intimidating. They had challenge with typing, lots of errors in typing chemical symbols and chemical reactions.

Learners in general express miss feeling when the issue of assessment is mention. It is worth noting that preservice teachers' expressed interest in assessment even though they are taken their lessons online. From the results of the study pre-service teachers' expressed great interest in tutors using trial questions and quiz in assessing them and responds from assessment should be submitted through what's up platform. The What's up platform was seen by the pre-service teachers'as easy to access and less expensive but poor network 
connectivity and funds for data or bundle still remains challenge. With all the challenges pre-service teachers' encounter during online teaching and learning they appreciated the tutor-learner relationship and interactions as cordial, collaborative and done in a form of discussion. Conversely, they expressed satisfaction with the previous semester interaction where teaching and learning was face to face classroom interaction than the current semesters online teaching and learning.

It is concluded that, despite gaining immense popularity today, digital technology has still not been embraced by the pre-service teachers' first year learners on the Primary Education atthe Offinso College of Education for use in teaching. Pre-service teachers' are still more inclined towards face to face teaching rather than online teaching and learning. Institution heads and department members should take necessary measures for improving online teaching and learning quality to help with better learning of pre-service teachers' during COVID - 19 crises. Based on the findings, it is clear pre-service teachers have content knowledge of the units covered during online teaching and learning interactions despite the few challenges identified. It is therefore recommended that there should be stable network connectivity and subside on data bundle for learners. Also tutor should be taking through internet etiquette to equip them with the necessary knowledge and skills to interact with learners. Tutors should facilitate online teaching and learning using videos and audio.

\section{Acknowledgement: Augustine Adjei, Dean of Students' Affairs- Offinso College of Education. Ashanti- Ghana W/A}

\section{References}

[1.] Abbasi, S.,Ayoob, T.,Malik, A. \&Memon, S. I. (2020).Perceptions of students regarding E learning during Covid-19 at a private medical college. Pakistan Journal of Medical Sciences, 36, S57-S61.

[2.] Cereijo, M. V. P., Young, J. \& Wilhelm, R. W. (2001). Factors facilitating student participation in asynchronous web-based courses. The Journal of Computing in Teacher Education. 18 (1).

[3.] Larbi-Apau, J., Sampong, K. \& Kwofie, B. (2020). Barriers to online learning adoption in higher education. $\quad$ Retrieved $\quad$ July $\quad 27, \quad 2020$ form https://www.universityworldnews.com/post.php?story=20200506200743715

[4.] Branch, M. R. \& Dousay, A. T. (2015). Survey of instructional design models, association for educational communications and technology (AECT). USA; Bloomington, Indiana.

[5.] Dempsey, J. V., \& Van Eck, R. N. (2002). Instructional design on-line: Evolving expectation. In R. A. Reiser, \& J. V. Dempsey (Eds.), Trends and issues in instructional design and technology. Pearson Education Inc.

[6.] Demuyakor, J. (2020). Coronavirus (covid -19) and online learning in higher institutions of education: a survey of the perceptions of Ghanaian international-students-in-china. Online Journal of Communication and Media Technologies, 10(3).

[7.] Dhawan, S. (2020). Online Learning: A panacea in the time of COVID-19 crisis.Journal of Educational Technology Systems 0(0), 1-18.

[8.] Figueroa, F., Figueroa, D., Calvo-Mena, F., Narvaez, F., Medina, N., and Prieto, J. (2020). A study carried out on orthopedic surgery residents' perception of online education in their programs during the COVID-19 pandemic: should it be maintained after the crisis? July 28, 2020. https://www.tandfonline.com/doi/pdf/10.1080/17453674.2020.1776461?needAccess=true

[9.] Hodges, C., Moore, S., Lockee, B., Torrey Trust, T. \& Bond, A. (2020). The difference between emergency remote teaching and online learning. Retrieved July 26, 2020 form https://er.educause.edu/articles/2020/3/the-difference-between-emergency-remote-teaching-andonline-learning.

[10.] Josep, G. (2020). 5 Reasons why online learning is the future of education. Retrieved, July 26, $2020 \mathrm{https}$ ///www.educations.com/articles-and-advice/5-reasons-online-learning-is- future-ofeducation-17146.

[11.] Kaden, U. (2020). COVID-19 School closure-related changes to the professional life of a k-12 teacher. Education Science, 10.

[12.] Kebritchi, M., Lipschuetz, A., Santiague, L. (2017). Issues and challenges for teaching successful online courses in higher education. Journal of Educational Technology Systems, 46(1), 4-29. 
[13.] Li, C. \& Lalani, F. (2020). The COVID-19 pandemic has changed education forever. This is how. Retrieved July 26, 2020 from https://www.weforum.org/agenda/2020/04/coronavirus- educationglobal-covid19-online-digital-learning/

[14.] Loeb, S. (2020). How effective is online learning? What the research does and doesn't tell us. Retrieved July 26, 2020 from https://www.edweek.org/ew/articles/2020/03/23/how- effectiveis-online-learning-what-the.html

[15.] Singh, V., \& Thurman, A. (2019). How many ways can we define online learning? A systematic literature review of definitions of online learning (1988-2018). American Journal of Distance Education, 33(4), 289-306.

[16.] UNESCO. (2020, Match 13). COVID -19 educational disruption and response. Retrieved from https://en.unesco.org/covid19/educationresponse 